\title{
Biosugar Production from Kappaphycus alvarezii by Hydrolysis Method using Fungi Trichoderma harzianum
}

\author{
St. Zaenab ${ }^{1 *}$, Kasmiati ${ }^{1}$, Sulfahri ${ }^{2}$, Asmi Citra Malina A.R. Tassakka ${ }^{1}$
}

\author{
${ }^{1}$ Departement of Fisheries, Faculty of Marine Science and Fisheries, Hasanuddin University, Jl. Perintis Kemerdekaan Km.10, Makassar \\ 90245, Indonesia \\ ${ }^{2}$ Departement of Biology, Faculty of Mathematics and Natural Science, Hasanuddin University, Jl. Perintis Kemerdekaan Km.10, \\ Makassar 90245, Indonesia \\ *Corresponding author
}

\begin{abstract}
Kappaphycus alvarezii is one of the natural resources containing high carbohydrate, and it has potential as an alternative raw material for sugar industry. This study aims to analyze the optimum conditions of the fungi Trichoderma harzianum in degradating polysaccharides from K. alvarezii into sugar. The seaweed was collected in Takalar Sea, South Sulawesi, Indonesia. The fungi was previously activated at $30^{\circ} \mathrm{C}$ for three days in $2 \%$ of seaweed substrate. The efficiency of the T. harzianum in producing biosugar was evaluated under various concentrations of inoculum (5\%, 10\%, 15\% and 20\%) and hydrolysis time $(0 \mathrm{~h}, 24 \mathrm{~h}, 48 \mathrm{~h}$, and $72 \mathrm{~h})$. The result implied that $K$. alvarezii contain 55,58\% of carbohydrate which was dominated by starch $35.83 \%$ and cellulose $12.21 \%$. Furthermore, the highest content of sugar indicated by $12,27 \mathrm{~g} / \mathrm{L}$ of reducing sugar was obtained at the combination of $20 \%$ of the fungi and $24 \mathrm{~h}$ incubation. In conclusion, the fungi $T$. harzianum has ability to convert carbohydrate of K.alvarezii to sugar through hydrolysis process.
\end{abstract}

Keywords—seaweed; K. alvarezii; biosugar; T. harzianum; hydrolysis.

\section{INTRODUCTION}

Sugar is one of the basic human needs consumed by all levels of society both for household and industrial needs. Indonesian sugar needs in 2018 reached 6.6 million tons while the production of sugar based sugarcane only 2.17 million tons (Ministry of Industry, 2018). This lead to a significant increase in sugar import. Nowadays, based on data from Statistical Central Agency in 2018, Indonesia became the largest sugar importer in the world, reaching 4.6 million tons (Katadata.co.id, 2018).

Sugarcane as the main raw material of sugar industry continues declining due to limited availability of cultivation land (IDN TIMES, 2019). Various raw alternatives of the sugar industry have been reported for instances cassava, corn, and sago containing high level of carbohydrates (Rahmawati et al., 2017; Mahyati et al., 2017). However, the availability of raw materials is limited because of its main function as staple foods. Therefore, it is necessary to search for other alternatives as raw materials which are rich carbohydrate based natural resources in abundant availability e.g. seaweeds.
Indonesia is the largest producer of seaweeds with a total production of 9,9 million tons in 2019 (kkp.go.id, 2020). This country has contributed almost $40 \%$ of the total world seaweed production (FAO, 2018). In general, seaweeds are widely used in food, engineering, and medicinal industries (S. W. Kim et al., 2015; Parenrengi \& Sulaeman, 2007). South Sulawesi is one of the seaweed producing center, especially the red seaweeds Kappaphycus alvarezii and Gracilaria sp with a total production of 2,4 million tons in 2013 and increasing to 3,6 million tons in 2017 (Department of Marine and Fisheries South Sulawesi, 2018). The abundance of seaweed $K$. alvarezii (65\% of the total production) becomes a potential alternative as raw material for sugar industry.

The constituent wall of seaweed cells consisted of agar, caragenan, cellulose, manan, and xylen can be converted into monosaccharides through various methods such as acid hydrolysis, enzymatic hydrolysis, hydrothermal, and fermentation (Meinita et al., 2015; Parenrengi \& Sulaeman, 2007). Several related studies have been reported, the hydrolysis of carbohydrates using 
sulfuric acid besides yielding high sugar it also has side toxic compounds (Carvalho et al., 2013). Decomposition of carbohydrates with hydrothermal methods showed less results due to high temperature causing damage of carbohydrate structure (D. H. Kim et al., 2014). The enzymatic hydrolysis produced high oligosaccharide, environmental friendly, low side effects of toxic compounds but took relatively long time with high cost (Vanegas. 2015).

Acceleration of hydrolysis of seaweed carbohydrate using microbe which has enzyme activity is an effective alternative method. The potential microbe used in degradation of carbohydrates through the hydrolysis method is the fungi Tricoderma harzianum because its cellulotic properties (Lee et al., 2017; Jamil et al., 2009). The enzyme produced by $T$. harzianum is about $25 \%$ more efficient than Trichoderma reesei (Souza et al., 2018). In the present study, we investigated biosugar production from the seaweed $K$. alvarezii using the fungi Tricoderma harzianum.

\subsection{Seaweed Materials}

\section{MATERIALS AND METHODS}

The sample $K$. alvarezii was collected from the Brackish Aquaculture Fisheries Hall, Takalar. It was washed with freshwater to remove attached mud and salts, then dried for two days. The dried seaweed was grinded using the hummer mill to obtain powder with size of 40 mesh.

\subsection{Culture of Trichoderma Harzianum}

The fungi $T$. harzianum was subcultured in a petri dish containing a PDA (Potato Dextrose Agar) medium and incubated at $30^{\circ} \mathrm{C}$ for $48 \mathrm{~h}$. The fungi culture was stored in a refrigerator before its further use.

\subsection{Activation process of Trichoderma Harzianum}

The Fungi T. harzianum was activated in three stages. (1) A small amount of sub cultured fungi was picked up and inoculated into $5 \mathrm{~mL}$ of seaweed media then shake incubated at $30^{\circ} \mathrm{C}$ for $24 \mathrm{~h}$. (2) $1 \mathrm{~mL}$ of the inoculum was diluted in $9 \mathrm{~mL}$ of seaweed media then incubated at the same condition of the previous stage. (3) $5 \mathrm{~mL}$ of the inoculum was activated in $45 \mathrm{~mL}$ of the seaweed media.

\subsection{Hydrolysis Process}

The hydrolysis process use seaweed that has been through the pretreatment process. The seaweed flour is dissolved in aquades and the heating process for $120 \mathrm{~min}$ with a warming temperature of $\pm 100^{\circ} \mathrm{C}$ and then cooled to a temperature of $\pm 40^{\circ} \mathrm{C}$. Then autoclave about $\pm 90 \mathrm{~min}$. Selected parameters for optimization in experimental hydrolysis using inoculum $\quad T$. harzianum with varying concentrations $(5 \%, 10 \%, 15 \%$ and $20 \%)$ and the duration hydrolysis ( $0 \mathrm{~h}, 24 \mathrm{~h}, 48 \mathrm{~h}$ and $72 \mathrm{~h})$. After the reaction, the supernatant were separated from liquid by centrifugation at a speed of 9.000 RPM for $10 \mathrm{~min}$. All preparation were performed at the Marine Microbiology Laboratory, Faculty of Marine Science and Fisheries, Hasanuddin University. The supernatant was collected to measured from the sugar level by the phenol sulfate acid.

\subsection{Data Analysis}

Data was analyzed by randomized design completed with factorial patterns. Total sugar was analyzed by two ways ANOVA to determine the influence of inoculum concentration and duration of hydrolysis on sugar production. If there was any influence, then proceed with the Tuckey test at a confidence level of $95 \%(\alpha=0.05)$ to identify the optimum combination indicated by the highest amount of sugar.

\section{RESULTS AND DISCUSSION}

\subsection{Analysis of carbohydrate content of seaweed $K$. alvarezii}

Carbohydrate content of the seaweed $K$. alvarezii was evaluated and obtained that it was about $55,58 \%$ dominated by starch and cellulose which were $35,83 \%$ and $12,21 \%$, respectively. Carbohydrates are also called polysaccharides which are combination of monosaccharides linked by the glycoside bonding, for instance polysaccharides are cellulose, glycogen, and starch.

Starch and cellulose are the main carbohydrates of K. alvarezii, other components are hemicellulose, pectin and lignin. Starch resulted in photosynthesis pathway of plants is deposited as energy for growing. It consists of amylose and amylopectin in different composition.

The seaweed $K$. alvarezii possesses starch higher than other seaweeds. This is supported by previous studies that Caulerpa lentillifera and Ulva Ohnoi contained starch of $29.82 \%$ and $21.4 \%$ (Tapotubun, 2018; Prabhu et al., 2019).

On the other hand, cellulose is the main polysaccharides of seaweed. Cellulose is one of the most abundant biopolymers in nature and the major component of plant cell wall (Börjesson \& Westman, 2015). It associates with other polysaccharides such as hemiselulose or lignin (Holtzapple et al., 2003). Thallus of seaweed also has cell wall consisting of cellulose (Linder \& Teeri, 1996). This study showed that $K$. alvarezii contained cellulose of $12.21 \%$. It is supported by previous research on the red algae Gracilaria reported by Sari et al. (2013) 
showing cellulose content of 20,17\%. In addition, Milala et al. (2005) described cellulose content in plants reaching $40-50 \%$ of plant mass. High polysaccharides on the seaweed $K$. alvarezii can be converted into mono sugar by hydrolysis method.

\subsection{Analysis of the effect of inoculum concentration on total sugar}

Pretreated seaweed was hydrolyzed using activated inoculum T. harzianum with various concentrations of $5 \%$, $10 \%, 15 \%$ and $20 \%$, and hydrolysis time $0 \mathrm{~h}, 24 \mathrm{~h}, 48 \mathrm{~h}$ and $72 \mathrm{~h}$. Samples were analyzed to determine the total sugar produced. Based on Two Way ANOVA and Tuckey test showed that the total sugar significant difference from each treatment $(\mathrm{p}<0,05)$. Figure 1. shows total sugar produced by every single treatment combination.

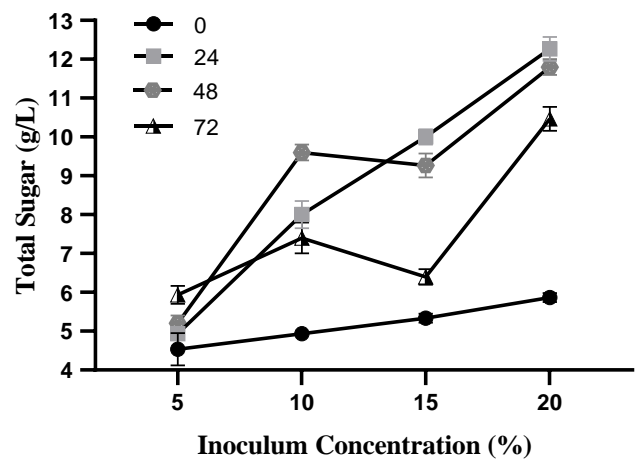

Fig.1: Total sugar from various inoculum concentration.

The result showed that generally, conversion of polysaccharide to total sugar increases due to increased inoculum concentration and hydrolysis time. The tendency is shown by the treatment of hydrolysis time 48 and 72 which increased to $10 \%$ inoculum concentration then decreased at a concentration of $15 \%$ and increased at the next concentration. Hydrolysis for $24 \mathrm{~h}$ showed an increase in sugar production with increasing inoculum concentration. The interesting from the results of this study is the control at the $0 \mathrm{~h}$ also shows the increase in total sugar with increasing inoculum concentration. Total sugar detected is sugar produced during the activation process of $T$. harzianum. Thus, the calculation of the total sugar produced must be corrected with the sugar content at the 0 $\mathrm{h}$ for all concentrations. The addition of $20 \%$ inoculum resulted in relatively equal total sugar after hydrolysis for 24 and 48 hours.

The hydrolysis process of carbohydrates into total sugars is carried out using the fungi T.harzianum with several parameters of concentration and duration of hydrolysis. Hydrolysis is a chemical reaction that splits a molecule into two parts by adding water molecules with the aim of converting polysaccharides into monosakarida. Cellulose is the main element of seaweed cell walls that can be degraded into monosugar by the hydrolysis process. Under normal conditions, only a few reactions occur during the hydrolysis process, therefore it is necessary to have a catalyst that can accelerate reactions such as the addition of acids, alkali or enzymes. Enzymes can work $10^{8}$ to $10^{11}$ times faster than the rate of reaction without a catalyst (Poedjadi, 2006).

T.harzianum produces cellulase enzymes that can degrade cellulotic substrates into sugar (Jamil et al., 2009). The use of microbes in hydrolysis provides the advantage of a fast process and does not produce toxic compounds. Souza et al., 2018 stated that $\beta$-glucosidase produced by $T$. harzianum strains was higher than $T$. reesei by using lactose as a carbon source.

The results indicated that the inoculum concentration and duration of hydrolysis have the significant effect on reducing sugars and there were significant interactions between the two treatments. The highest reducing sugar was $12,2 \mathrm{~g} / \mathrm{L}$ obtained from an inoculum concentration of $20 \%$ and a hydrolysis duration of $24 \mathrm{~h}$. Moreover, the lowest reducing sugar is at 5\% inoculum concentration treatment and $0 \mathrm{~h}$ hydrolysis time. Figure 1. shows the tendency to total sugar levels increases with increasing inoculum concentration. This research indicated that the activity of $T$. harzianum in hydrolyzing cellulose to sugar increases with increasing inoculum concentration. However, high cellulose content in seaweed is a source of carbon needed to obtain energy for the growth of $T$. harzianum in producing cellulase enzymes and degrading cellulose into monosugars. Ul-Haq et al., 2005 stated Trichoderma sp. is a producer of cellulases and crude enzymes. T. harzianum is a potential fungus in producing cellulase enzymes that can hydrolyze chain $\beta$ glucosidase (cellobiase) that break down cellobiose to produce glucose (Wang et al., 2020). The fungi also produces higher levels of cellulolytic activity and $\beta$ glucosidase activity compared to $T$. reesei (Souza et al., 2018).

The carbohydrates contained in K. Alvarezii are applicative media for the Trichoderma growth. High cellulose and starch elements in the substance can be potential source of nutrients for fungal growth. The 20 percent concentration of inoculum seaweed into the media can produce high cellulase enzymes for the degradation of carbohydrates into monosaccharides. Brijwani et al. (2010) stated that $T$. Harzianum has ability to produce enzymes by the growth medium consisting of nitrogen and carbon. The results of the research of Yong Syuan et al. (2018) shows 
rice straw as substrate of $T$. Harzianum potentially produce cellulase and xylanase. Higher substrate concentrations indicate the number of molecular substrates involved with enzyme activity. Morever, low substrate concentrations mean fewer substrate molecules that can be attached to the enzyme causing reduced enzyme activity.

\subsection{Analysis of the effect of hydrolysis time on total sugar}

The hydrolysis time affects the total sugar produced. This is related to the ability of the fungi T.harzianum in degrading carbohydrates into monosugar. Based on the Tuckey test, it showed the significant difference between treatments $(\mathrm{P}<0.05)$.

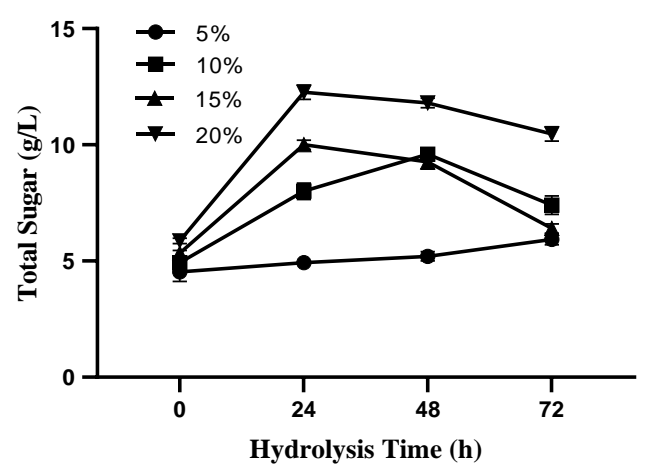

Fig.2: Total sugar from various hydrolysis time

The hydrolysis time affects the total sugar produced. This is related to the activity of T. harzianum which able to produce cellulase enzymes to degrade carbohydrates. The treatments with concentrations of 15 and $20 \%$ showing a significant increase in the incubation time of $24 \mathrm{~h}$ and decreasing in the following hours (Figure 2). This shows that the cellulase enzyme produced by $T$. harzianum is only able to work for a maximum of $24 \mathrm{~h}$. In the treatment of 48 $\mathrm{h}$ and $72 \mathrm{~h}$ the enzyme activity decreases as indicated by a decrease in sugar levels.

To increase reducing sugar levels from $0 \mathrm{~h}$ to $24 \mathrm{~h}$ shows the activity of T.harzianum in producing cellulose enzymes to degrade carbohydrates from $K$. alvarezii seaweed. Treatment with an inoculum concentration of $20 \%$ is an excellent source of nutrition for T. harzianum to produce enzymes. At the beginning of the hydrolysis process, there are many sources of nutrients for $T$. harzianum available. After $24 \mathrm{~h}$, growth nutrients for $T$. harzianum are reduced because they have been used in producing enzymes to degrade seaweed carbohydrates. This causes the concentration of the enzyme to become unbalanced, causing the enzyme performance to also decrease.
Treatment with an inoculum of $20 \%$ concentration after $24 \mathrm{~h}$ showed the amount of reducing sugar produced from the hydrolysis process decreased. This is caused by the accumulation of the final product of the hydrolysis process which inhibits the performance of the cellulase enzyme (Binod et al., 2019). Glucose and ethanol are the end products that can inhibit cellulase performance (Chen \& Jin, 2006). At constant seaweed substrate concentrations, the rate of enzymatic reaction increases with increasing enzyme concentration. This indicated that the more enzymes to a certain extent, the more substrates are converted because the higher the enzyme activity. In addition, enzymes are specific to the substrate, excessive concentrations will also affect the rate of the enzymatic reaction.

\section{CONCLUSIONS}

This research has provided information about the potential of seaweed which used as raw material for producing sugar. Previous studies have shown in sugar production from seaweed uses several methods. However, this study is the first method using $T$. harzianum in degrading polysaccharides into monosugar. The finding of this research can demonstrated the ability of T.harzianum to convert carbohydrate from the $K$. alvarezii to biosugar production through the hydrolysis process.

\section{ACKNOWLEDGMENTS}

Special thanks to LPDP for providing funding for this research.

\section{REFERENCES}

[1] [FAO] 2018. The Global Status of Seaweed Production, Trade and Utilization Vol. 124. Roma.

[2] [Departement of Marine and Fisheries South Sulawesi] 2018. Seaweed production data of South Sulawesi Province.

[3] Binod, P., Sindhu, R., Janu, K. U., \& Pandey, A. (2019). Hydrolysis of cellulosic and hemicellulosic biomass. Biomass, Biofuels, Biochemicals: Biofuels: Alternative Feedstocks and Conversion Processes for the Production of Liquid and Gaseous Biofuels, 447-460. https://doi.org/10.1016/B978-0-12-816856-1.00019-1

[4] Börjesson, M., \& Westman, G. (2015). Crystalline Nanocellulose - Preparation, Modification, and Properties. Cellulose - Fundamental Aspects and Current Trends. https://doi.org/10.5772/61899

[5] Brijwani, K., Oberoi, H. S., \& Vadlani, P. V. (2010). Production of a cellulolytic enzyme system in mixed-culture solid-state fermentation of soybean hulls supplemented with wheat bran. Process Biochemistry, 45(1), 120-128. https://doi.org/10.1016/j.procbio.2009.08.015 
[6] Carvalho, A. F. A., Neto, P. de O., da Silva, D. F., \& Pastore, G. M. (2013). Xylo-oligosaccharides from lignocellulosic materials: Chemical structure, health benefits and production by chemical and enzymatic hydrolysis. Food $\begin{array}{lll}\text { Research } & \text { International, }\end{array}$ https://doi.org/10.1016/j.foodres.2012.11.021

[7] Chen, H., \& Jin, S. (2006). Effect of ethanol and yeast on cellulase activity and hydrolysis of crystalline cellulose. Enzyme and Microbial Technology, 39(7), 1430-1432. https://doi.org/10.1016/j.enzmictec.2006.03.027

[8] IDN TIMES. (2019). [Sugarcane Farmers' Productivity Decreases, Ministry of Agriculture Targets 3 Million Tons of Sugar].

https://www.idntimes.com/business/economy/indianamalia/p roduktivitas-petani-tebu-menurun-kementan-targetkan-3juta-ton-gula/4

[9] Jamil, A., Ahmed, S., \& Al, E. T. (2009). Production and Purification of Cellulose- Degrading Enzymes From a Filamentous Fungus. Pak. J. Bot., 41(3), 1411-1419.

[10] katadata.co.id. (2018). [Indonesia's Largest Sugar Importers in the World 2017/2018]. Im, 1-7. https://databoks.katadata.co.id/datapublish/2019/01/09/indon esia-importir-gula-terbesar-dunia-20172018

[11] Kim, D. H., Lee, S. B., \& Jeong, G. T. (2014). Production of reducing sugar from Enteromorpha intestinalis by hydrothermal and enzymatic hydrolysis. Bioresource Technology, 161, 348-353. https://doi.org/10.1016/j.biortech.2014.03.078

[12] Kim, S. W., Hong, C. H., Jeon, S. W., \& Shin, H. J. (2015). High-yield production of biosugars from Gracilaria verrucosa by acid and enzymatic hydrolysis processes. Bioresource Technology, 196, 634-641. https://doi.org/10.1016/j.biortech.2015.08.016

[13] kkp.go.id. (2020). Siaran pers. [To Boost Export Value, KKP Targets 10.99 Million Tons of Seaweed Production in 2020]. [Internet]; cited 29 Januari 2020; Available from: https://doi.org/10.1111/1540-5885.1110069

[14] Lee, H., Min, Y., Mok, Y., Lee, J., Seok, J., Young, K., \& Kim, J. (2017). Industrial Crops \& Products Utilization of agricultural residues for enhancement of cellulolytic enzyme production and enzymatic sacchari fi cation by Trichoderma harzianum. Industrial Crops \& Products, 109(April), 185191. https://doi.org/10.1016/j.indcrop.2017.08.042

[15] Linder, M., \& Teeri, T. T. (1996). The cellulose-binding domain of the major cellobiohydrolase of Trichoderma reesei exhibits true reversibility and a high exchange rate on crystalline cellulose. Proceedings of the National Academy of Sciences of the United States of America, 93(22), 1225112255. https://doi.org/10.1073/pnas.93.22.12251

[16] Meinita, M. D. N., Marhaeni, B., Winanto, T., Setyaningsih, D., \& Hong, Y. K. (2015). Catalytic efficiency of sulfuric and hydrochloric acids for the hydrolysis of Gelidium latifolium (Gelidiales, Rhodophyta) in bioethanol production. Journal of Industrial and Engineering Chemistry, 27, 108-114 https://doi.org/10.1016/j.jiec.2014.12.024

[17] Milala, M., Shugaba, A., Gidado, A., Ene, A., \& Wafar, J.
(2005). Studies on the Use of Agricultural Wastes for Cellulase Enzyme Production by Aspegillus niger. Research Journal of Agriculture and Biological Sciences, 1(4), 325328.

[18] Ministry of Industry. (2018). [Sugar Industry Boosted. 18 Maret 2019. [Internet] cited : 10 Oktober 2020]; Available from: https://kemenperin.go.id/artikel/20447/Industri-GulaDigenjot

[19] Parenrengi, A., \& Sulaeman. (2007). [Get to know Seaweed, Kappaphycus alvarezii]. In Media Akuakultur (Vol. 2, Issue 1, pp. 142-146).

[20] Prabhu, M., Chemodanov, A., Gottlieb, R., Kazir, M., Nahor, O., Gozin, M., Israel, A., Livney, Y. D., \& Golberg, A. (2019). Starch from the sea: The green macroalga Ulva ohnoi as a potential source for sustainable starch production in the marine biorefinery. Algal Research, 37(November 2018), 215-227. https://doi.org/10.1016/j.algal.2018.11.007

[21] Sari, R. N., Sugiyono, S., \& Assadad, L. (2013). [Optimization of Hydrolysis and Fermentation Process Time in Bioethanol Production from Industrial Agar (Gracilaria sp.) waste]. Jurnal Pascapanen Dan Bioteknologi Kelautan Dan Perikanan, $8(2), \quad 133$. https://doi.org/10.15578/jpbkp.v8i2.57

[22] Souza, M. F. de, Silva, A. S. A. da, \& Bon, E. P. S. (2018). A novel Trichoderma harzianum strain from the Amazon Forest with high cellulolytic capacity. Biocatalysis and Agricultural Biotechnology, 14(October 2017), 183-188. https://doi.org/10.1016/j.bcab.2018.03.008

[23] Tapotubun, A. M. (2018). [Chemical Composition of Seaweed (Caulerpa lentillifera) from Maluku Kei Waters with Different Drying Methods]. Jurnal Pengolahan Hasil Perikanan Indonesia, 21(1), 13. https://doi.org/10.17844/jphpi.v21i1.21257

[24] Ul-Haq, I., Javed, M. M., Khan, T. S., \& Siddiq, Z. (2005). Cotton Saccharifying Activity of Cellulases Produced by Co-culture of Aspergillus niger and Trichoderma viride. Journal of Agriculture and Biological Sciences, 1(3), 241245.

[25] Wang, H., Zhai, L., \& Geng, A. (2020). Enhanced cellulase and reducing sugar production by a new mutant strain Trichoderma harzianum EUA20. Journal of Bioscience and Bioengineering, 129(2), 242-249. https://doi.org/10.1016/j.jbiosc.2019.08.016

[26] Yong Syuan, K., Ong Gaik Ai, L., \& Kim Suan, T. (2018). Evaluation of cellulase and xylanase production from Trichoderma harzianum using acid-treated rice straw as solid substrate. Materials Today: Proceedings, 5(10), 2210922117. https://doi.org/10.1016/j.matpr.2018.07.077 